\begin{tabular}{|c|c|c|}
\hline & Int.J.Curr.Microbiol.App.Sci (2016) 5(3): 194-205 & \\
\hline & International Journal of Current Microbiology and Applied Sciences & 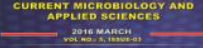 \\
\hline & ISSN: 2319-7706 Volume 5 Number 3(2016) pp. 194-205 & \\
\hline EXCELLENT & Journal homepage: http://www.ijcmas.com & \\
\hline PUBLISHERS & & wwwwijemas.com \\
\hline
\end{tabular}

Original Research Article

http://dx.doi.org/10.20546/ijcmas.2016.503.024

\title{
Multiplex Polymerase Chain Reaction for Klebsiella pneumoniae Metallo- $\beta$-lactamase Causing Neonatal Sepsis in Mansoura Children University Hospital in Egypt
}

\author{
Maggie R. Mesbah ${ }^{1}$, Maysaa El Sayed Zaki" and Mona Abdel Latif Alsayed ${ }^{3}$ \\ ${ }^{1}$ Medical Microbiology and Immunology Department Mansoura Faculty of Medicine, Egypt, \\ ${ }^{2}$ Clinical Pathology Department Mansoura Faculty of Medicine, Egypt \\ ${ }^{3}$ Pediatric Department, Mansoura Faculty of Medicine, Egypt \\ *Corresponding author
}

\begin{tabular}{|c|c|}
\hline & A B S T R A C T \\
\hline & $\begin{array}{l}\text { The present study was conducted to detect the presence of MBLs among the } \\
\text { isolates of Klebsiella pneumoniae by phenotypical methods and genotypic } \\
\text { multiplex polymerase chain reaction (PCR) method among neonates with sepsis. } \\
\text { The study included neonates who were admitted to the neonatal intensive care unit } \\
\text { (NICU) and had suspected sepsis after hospital admission. A full laboratory sepsis }\end{array}$ \\
\hline Keywords & $\begin{array}{l}\text { screen for each neonate was performed and included cerebrospinal fluid analysis, } \\
\text { blood cultures using BACT/Alert blood culture system and urine culture. Aerobic }\end{array}$ \\
\hline $\begin{array}{l}\text { Klebsiella } \\
\text { pneumoniae, } \\
\text { IMP, }\end{array}$ & $\begin{array}{l}\text { bacteria were identified using Microscan automated microbiological system. } \\
\text { Bacterial isolates defined as Klebsiella pneumoniae were further subjected to } \\
\text { microbiological laboratory studies including antibiotics susceptibility tests by disc }\end{array}$ \\
\hline $\begin{array}{l}V I M \\
N D M\end{array}$ & $\begin{array}{l}\text { diffusion method, determination of MBLs production by double discs and } \\
\text { combined disc methods and determination of genotypes of MBLs-Klebsiella }\end{array}$ \\
\hline Article Info & \\
\hline $\begin{array}{l}\text { Accepted: } \\
15 \text { February } 2016 \\
\text { Available Online: } \\
\text { 10, March } 2016\end{array}$ & $\begin{array}{l}\text { genotypes respectively. The most common identified gene responsible for MBLs- } \\
\text { Klebsiella pneumoniae was VIM }(69.2 \%) \text { followed by IMP and NDM }(23.1 \% \text { for } \\
\text { each) and mixed genotypes were identified in } 23.1 \% \text {. We can conclude from this } \\
\text { study that carbapenemase production is a common finding among the isolates of }\end{array}$ \\
\hline & $\begin{array}{l}\text { Klebsiella pneumoniae among neonates with sepsis. Both double discs and } \\
\text { combined discs methods are accurate as screening tool for detection of resistance to } \\
\text { carbapenem drugs. Genotypes responsible for MBLs determined VIM and IMP } \\
\text { genes as the main prevalent genes beside NDM. Extensive studies should be } \\
\text { carried out to determine the prevalence of MBLs- Klebsiella pneumoniae other } \\
\text { geographic locations in Egypt to assess the magnitude of the problem. Antibiotics } \\
\text { tigecycline and colistin are suitable for treatment under strict laboratory supervision } \\
\text { and strict infection control practices and antibiotic policies should be strengthened } \\
\text { to avoid the blowout of these microbial bums in our hospitals. }\end{array}$ \\
\hline
\end{tabular}




\section{Introduction}

Neonatal sepsis is a significant health problem associated with recognizable high risks of morbidity and mortality. Several factors attribute to such grave condition among with but not limited to prematurity, low birth weight and prolonged hospital stay. The expanded use of antimicrobial therapy has led to colonization and subsequent infections by virulent bacterial pathogens (1). Various bacterial pathogens are associated with this infection either Gram positive cocci such as coagulase negative Staphylococcus and group B Streptococcus and Gram negative bacilli like Escherichia coli and Klebsiella species(2).

The frequency of isolated bacterial pathogens differs according to the geographic localities and according to impact of antibiotics prescription selecting resistant pathogens. In developing countries, like Egypt, multiple drug resistant organisms are reported to increase due to many factors. Klebsiella pneumoniae (K. pneumoniae) is associated with these infections in Egypt as previously reported $(3,4)$.

Klebsiella pneumoniae isolates are shown to have multiple mechanisms mediating antibiotic resistance. Isolates have been reported to express extended spectrum betalactamases (ESBLs), AmpC betalactamases, $16 \mathrm{~S}$ rRNA methylases, aminoglycoside modifying enzymes and metallo-beta-lactamase (MBL) (5).

MBL producing bacteria hydrolyze wide group beta-lactam antibiotics including cephalosporins, penicillins, carbapenems, cephamycins, yet it remains susceptible to aztreonam. The hydrolysis capacity of MBL are not suppressed by the presence of other $\beta$ - lactamase inhibitors such as clavulanate and sulbactam (6).These enzymes are classified as class B beta-lactamases depending on the chemical structure and

amino acid sequence homology and to group 3 according to the Bush classification according to their substrate and inhibitors used for their detection $(7,8)$. It is known that the action of MBL require the presence of zinc ions for the hydrolysis of beta-lactam antibiotics thus its action is inhibited in presence of metal-chelating substances like ethylenediaminetetra acetic acid (EDTA) (8). The genes coding for MBL are part of the chromosome and can be transferred by horizontal gene transfer from resistant species to susceptible species (6). MBLs were reported firstly to be common among Pseudomonas aeruginosa and Acinetobacter spp., later on, it has emerged to members of Enterobacteriaceae (9).

MBLs production by clinical isolates from Klebsiella pneumoniae represents therapeutic challenges. Infections with MBLs Klebsiella pneumoniae strains need to be treated with drugs such as tigecycline or colistin, which clinicians are becoming increasingly dependent on for treatment of such infections (10)

Thus laboratory detection of MBLs Klebsiella pneumoniae among clinical isolates has a major influence on therapeutic trends in clinical situations. There are many phenotypic methods proposed by CLSI for detection of MBLs (11,12). Genotypic methods are available for detection of genes coding MBL. The common reported MBLs genes are the VIM and IMP types, with recently recognized NDM-1, gene started to spread (13).

Studies about the incidence of MBLs Klebsiella pneumoniae among clinical isolates from Egypt especially in neonates are scarce (14). 
The present study was conducted to detect the presence of MBLs among the isolates of Klebsiella pneumoniae by phonotypical methods and genotypic multiplex polymerase chain reaction (PCR) method among neonates with sepsis.

\section{Materials and Methods}

The study was carried out in Mansoura University Children Hospital between March 2014 till November 2015. The study included 100 neonates who were admitted to the neonatal intensive care unit (NICU) and had suspected sepsis after hospital admission. Sepsis was defined according to Egyptian Neonatal Network (EGNN) by finding at least 3 criteria (15) i-the presence of risk factors for development of sepsis like prematurity, (ii) the presence of two or more clinical signs of sepsis (poor reflexes, lethargy, respiratory distress, bradycardia, apnea, convulsions, abdominal distension, and bleeding),(iii)abnormal hemogram and positive CRP and positive culture.

A full laboratory sepsis screen for each neonate was performed and included cerebrospinal fluid analysis blood cultures using BACT/Alert blood culture system and urine culture. Aerobic bacteria were identified using Microscan automated microbiological system (Beckman coulter). Hematologic parameters, including a complete blood picture and CRP were measured at the time of sepsis evaluation. Parenteral antibiotics were started immediately after the samples for the infection screen had been obtained.

Bacterial isolates defined as Klebsiella pneumoniae were further subjected to microbiological laboratory studies including antibiotic susceptibility tests by disc diffusion method, determination of MBLs production by double discs and combined discs methods and determination of genotypes of MBLs-Klebsiella pneumoniae by multiplex PCR.

\section{Antibiotic Susceptibility by Disc Diffusion Method}

Antimicrobial susceptibility testing for isolated Klebsiella pneumoniae was performed by the Kirby-Bauer disc diffusion method on Mueller-Hinton agar (Oxoid) according to the recommendations of the CLSI (2010) (11). The antibiotics used were: ampicillin $(10 \mu \mathrm{g})$, cephalexin (30 $\mu \mathrm{g})$, cefotaxime $(30 \mu \mathrm{g})$, ceftazidime (30 $\mu \mathrm{g})$, ceftriaxone $(30 \mu \mathrm{g})$, cefepime $(30 \mu \mathrm{g})$, aztreonam $(30 \mu \mathrm{g})$, piperacillin/tazobactam $(100 / 10 \mu \mathrm{g})$, imipenem $(10 \mu \mathrm{g})$, meropenem $(10 \mu \mathrm{g})$, amikacin $(30 \mu \mathrm{g})$, tigecycline (15 $\mu \mathrm{g})$ and colistin $(10 \mu \mathrm{g})$.

Klebsiella pneumoniae isolate with a reduced susceptibility to meropenem or imipenem (inhibition zone diameter of $\leq 21$ $\mathrm{mm}$ ) was screened for the production of carbapenemase according to the standard guidelines (11) by both combined discs and by double discs methods.

Simply, Klebsiella pneumoniae suspension equal to a 0.5 McFarland standard suspension of was prepared to be used as a culture inoculum for combined discs tests and double discs test.

\section{Detection of Metallo-beta-lactamase Production by Combined Discs Test}

Freshly prepared Muller Hinton agar was inoculated with $0.5 \mathrm{McF}$ arland suspension of Klebsiella pneumoniae and two imipenem discs were used with concentration $10 \mu \mathrm{g}$, one containing $10 \mu \mathrm{l}$ of $0.1 \mathrm{M}(292 \mu \mathrm{g})$ anhydrous EDTA (Sigma Chemicals, St. Louis, MO) and other with imipenem only. Plates were incubated at $37^{\circ} \mathrm{C}$ for 24 hours. 
After incubation, the diameter of inhibition zones was measured. An increase in zone diameter of $>4 \mathrm{~mm}$ around the imipenemEDTA disc compared to that of the plain imipenem disc alone was considered positive for MBL production (Franklin et al. (16).

\section{Double Discs for MBLs-Klebsiella pneumoniae}

Disks containing $10 \mu \mathrm{l}$ of the EDTA solution with concentration of $0.5 \mathrm{M}$ were prepared using sterile EDTA solution added to sterile blank $6 \mathrm{~mm}$ disk prepared from Whatman filter. Freshly prepared Muller Hinton agar was inoculated with 0.5 McFarland suspension of Klebsiella pneumoniae and 10 $\mu \mathrm{g}$ meropenem disk was placed at the center of the plate and the $10 \mu \mathrm{l}$ of the EDTA disk was place at a distance of $10 \mathrm{~mm}$ center to center, and the plate was incubated at $37^{\circ} \mathrm{C}$ overnight. The zone around the meropenem disk extended on the side nearest the EDTA $>7 \mathrm{~mm}$ indicated organism was a MBL producer.

\section{Molecular Detection of MBLs-Genes by Multiplex PCR}

Klebsiella pneumoniae isolates identified by screening methods to be MBLs producers were subjected to genotypes studies.

\section{Bacterial DNA Extraction}

Isolation of Bacterial DNA was obtained from colonies grown overnight on blood agar using a QIAamp DNA Mini Kit Qiagen, Valencia, CA, USA) according to the manufacturer's instructions. Extracted DNA was kept frozen at $-70^{\circ} \mathrm{C}$ until amplification.

\section{Multiplex PCR}

Amplification procedures were performed using specific primers for three genes namely VIM, IMP and NDM according to primers sequences summarized in table 1. Total DNA from isolates was subjected to multiplex PCR using a PCR kit (Qiagen) according to the manufacturer's instructions. Briefly, 200pg of DNA was added to 20 microns of amplification mixture and the amplification was performed by ABI 9700 thermocycler (Applied Biosystems, Carlsbad, CA, USA) (19). The amplified products were separated in $1.5 \%$ agarose gel ethidium bromide. The gel was run at $70 \mathrm{~V}$ for 1 hour. The gel images were taken under ultraviolet light and $100 \mathrm{bp}$ ladder molecular weight markers was used to measure the molecular weights of amplified products.

\section{Statistical Analysis}

All the statistical analyses were performed using SPSS16. Summary of measures was reported as mean \pm standard deviation $(\mathrm{SD})$ for quantitative variables and percentages for categorical variables. The differences in distribution were evaluated using the chisquare test for categorical variables. Value $\leq$ 0.05 was considered statistically significant.

\section{Results and Discussion}

Demographic data and culture results for the studied neonates are summarized in table 2 . The studied neonates with suspected sepsis were mainly preterm 60\% with male $45 \%$ and females 55\%. Previous antibiotics therapy was prescribed for $20 \%$ of those patients. Survival rate was $85 \%$.Blood culture was positive in $55 \%$ of cases.

The isolated bacterial pathogens were Staphylococcus species 28 (50.9\%) and Klebsiella pneumoniae 27(49.1\%), figure 1 .

MBLs-Klebsiella pneumoniae was detected among $13(48.1 \%)$ by double discs, combined discs and genotypes respectively, table 3 . 
The most common identified gene responsible for MBLs-Klebsiella pneumoniae was VIM (69.2\%) followed by IMP and NDM (23.1\% for each) and mixed genotypes were identified in $23.1 \%$, table 4 .

In comparison for susceptibility for antibiotics between MBLs and non MBLs Klebsiella pneumoniae there was significantly reduced susceptibility among MBLs-Klebsiella pneumoniae compared to non MBLs- Klebsiella pneumoniae to ampicillin, cefotaxime, cefipime, ceftazidime, ceftriaxone, meropnem, imipnem, piperacillin/ tazobactam $(\mathrm{P}=0.003$, $\mathrm{P}=0.07, \mathrm{P}=0.02, \mathrm{P}=0.01, \mathrm{P}=0.01, \mathrm{P}=0.001$, $\mathrm{P}=0.001, \mathrm{P}=0.01$ ), while susceptibility to amikacin, tigecycline, aztreonam, and colistin had no statistically significant difference, table 5 .

Sepsis in neonates is one of common health problem associated with morbidity and mortality worldwide. The problem is claimed to be responsible for around of 30$50 \%$ of total neonate's deaths in developing countries $(20,21)$. In the present study the mortality rate among the studied neonates was $15 \%$ the majority were preterm. Prematurity is a major implicated risk factor for developing neonatal sepsis as it leads to many interventional invasive procedures like parenteral nutrition, mechanical ventilation and prolonged hospital stay $(22,23)$.

In the present cohort of neonates, the isolated bacterial pathogens were Staphylococcus species and Klebsiella pneumoniae. Similar data were reported previously denoting that Gram positive organisms account for about $70 \%$ of all late onset sepsis and the most common Gramnegative organism causing neonatal sepsis was Klebsiella pneumoniae (24-26). The main source of bacterial pathogens causing neonatal sepsis in NICU is the colonization of the infant's body sites like skin from the environment leading to late onset sepsis (27).

Among 100 neonates studied for sepsis, $55 \%$ were confirmed to have bloodstream infection by using blood culture. This rate is comparable to rates reported in other developing countries where the rates ranged from $37 \%$ up to $55.6 \%$ (29-31). In contrast, very low rates $(2.27 \%)$ was reported by $l i$., et al., 2013 (32), which can be explained by the strict adherence to infection control guidelines in health care settings to prevent health care associated infections in NICU in these countries.

The alarming notice in the present study regarding isolated Klebsiella pneumoniae was the high percentage $(48.1 \%)$ of MBLs strains. Resistance to carbapenem has been reported in previous reports from different regions (33-35). In recent study the MBLs Klebsiella strains isolated from Italian ICU were found among $59.2 \%$ of the isolates (36). In Europe, carbapenem-resistant $K$. pneumoniae is reported to be high and even increasing in some countries (37). Carbapenem- resistant $K$. pneumoniae isolates are frequently found to be carbapenemase-producing, these results indicate the potential needs for active screening of patients at high-risk of acquiring these strains with adequate implementation of infection control guidelines and the stepwise use of antimicrobials $(37,38,39)$

Resistant to carbapenems among K.pneumoniae are worrisome because these antibiotics are last line antibiotics for treatment of such bacterial pathogens. Moreover, the presence of carbapenems resistance due to the presence of carbapenemases are usually associated with extensively drug- or pandrug-resistant 
leaving few or no effective treatment options (38-41). In Egypt, we could not find data except from limited studies on few isolates confirming the emergence of MBLsKlebsiella pneumoniae (14).

Prompt start of efficient antibiotic therapy is mandatory for early management of neonatal sepsis and must depend upon proper studies of the distribution of pathogens in each hospital and their susceptibility patterns according to laboratory findings. In a setting where MBLs producers are reported, empirical treatment of sepsis should ideally include drugs that will be effective against these pathogens. All the isolated K. pneumoniae with MBLs production in the present study were found to be resistant to both imipenem and meropenem. These isolates also had a high level of resistance to ampicillin, the third generation cephalosporins as well as to the beta-lactam/beta-lactamase inhibitor combination used in this study compared to non MBLs- Klebsiella pneumoniae. This is well known finding reported previously (42).

Table.1 Primers Sequences, Used for Genes Amplifications

\begin{tabular}{|l|l|l|l|}
\hline Gene & Sequence & bp & Ref. \\
\hline VIM & $\begin{array}{l}\text { F-5/ GATGGTGTTTGGTCGCATA-/3 } \\
\text { R-5/ CGAATGCGCAGCACCAG-/3 }\end{array}$ & 390 & $(17)$ \\
\hline IMP & $\begin{array}{l}\text { F-5/ GGAATAGAGTGGCTTAAYTCTC-/3 } \\
\text { R-5/ CCAAACYACTASGTTATCT-/3 }\end{array}$ & 232 & $(18)$ \\
\hline NDM & $\begin{array}{l}\text { F-5/ CACCTCATGTTTGAATTCGCC-/3 } \\
\text { R- R-5/ CTCTGTCACATCGAAATCGC-/3 }\end{array}$ & 984 & $(19)$ \\
\hline
\end{tabular}

Table.2 Demographic Data and Culture Results of the Studied Neonates

\begin{tabular}{|l|l|}
\hline Parameter & $\mathrm{No}(100) \%$ \\
\hline Sex & \\
Male & $45(45 \%)$ \\
Females & $55(55 \%)$ \\
\hline Full term & $40(40 \%)$ \\
Preterm & $60(60 \%)$ \\
\hline Survival & \\
No & $15(15 \%)$ \\
Yes & $85(85 \%)$ \\
\hline Previous antibiotics therapy & \\
Yes & $20(20 \%)$ \\
No & $80(80 \%)$ \\
\hline Culture & \\
No growth & $45(45 \%)$ \\
Positive culture & $55(55 \%)$ \\
\hline
\end{tabular}


Table.3 Metalobetalactamase Determination by Phenotypic and Genotypic Methods

\begin{tabular}{|l|l|}
\hline & No. \% \\
\hline $\begin{array}{l}\text { MBLs-Klebsiealla } \\
\text { pneumoniae by combined } \\
\text { disc }\end{array}$ & $13(48.1 \%)$ \\
\hline $\begin{array}{l}\text { MBLS -Klebsiella } \\
\text { pneumoniae by genotypes }\end{array}$ & $13(48.1 \%)$ \\
\hline
\end{tabular}

Table.4 Genetic Distributions among MBLs-Klebsiella pneumoniae

\begin{tabular}{|l|l|}
\hline Genotypes & No. $\%$ \\
\hline VIM & $9(69.2 \%)$ \\
\hline IMP & $3(23.1 \%)$ \\
\hline NDM & $3(23.1 \%)$ \\
\hline Mixed & $3(23.1 \%)$ \\
\hline
\end{tabular}

Table.5 Comparison between Antibiotics Susceptibility between MBLs- and Non MBLs -Klebsiella pneumoniae Species

\begin{tabular}{|l|l|l|l|}
\hline Antibiotics & $\begin{array}{l}\text { MBLs-Klebsiella } \\
\text { pneumoniae } \\
(\mathrm{n}=13)\end{array}$ & $\begin{array}{l}\text { Non MBLs-Klebsiella } \\
\text { pneumoniae } \\
\mathrm{n}=14)\end{array}$ & P value \\
\hline amikcin & $5(38.5 \%)$ & $10(71.4 \%)$ & 0.4 \\
\hline ampicillin & $1(7.6 \%)$ & $11(78.6 \%)$ & 0.003 \\
\hline azteronam & $8(61.5 \%)$ & $14(100 \%)$ & 0.4 \\
\hline cephalexin & $3(23.1 \%)$ & $11(78.6 \%)$ & 0.02 \\
\hline cefipime & $2(15.4 \%)$ & $10(71.4 \%)$ & 0.02 \\
\hline tigecycline & $13(100 \%)$ & $14(100 \%)$ & 0.9 \\
\hline colistin & $12(92.3 \%)$ & $14(100 \%)$ & 0.6 \\
\hline cefotaxime & $3(23.1 \%)$ & $12(85.7 \%)$ & 0.07 \\
\hline ceftazidime & $2(15.4 \%)$ & $14(100 \%)$ & 0.01 \\
\hline ceftriaxone & $3(23.1 \%)$ & $12(85.7 \%)$ & 0.01 \\
\hline meropenem & $0(0 \%)$ & $14(100 \%)$ & 0.001 \\
\hline imipenem & $0(0 \%)$ & $14(100 \%)$ & 0.001 \\
\hline piperacillin/tazobactam & $2(15.4 \%)$ & $14(100 \%)$ & 0.01 \\
\hline P & & &
\end{tabular}

$P$ value $<0.01$ is significant 
Figure.1 Isolated Bacteria from Positive Blood Culture

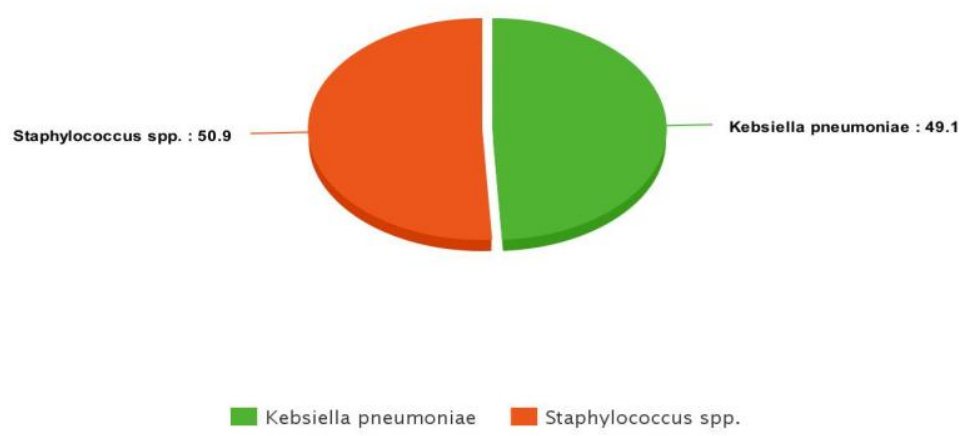

Figure.2 Marker and Positive Klebsiella pneumoniae for IMP Genes

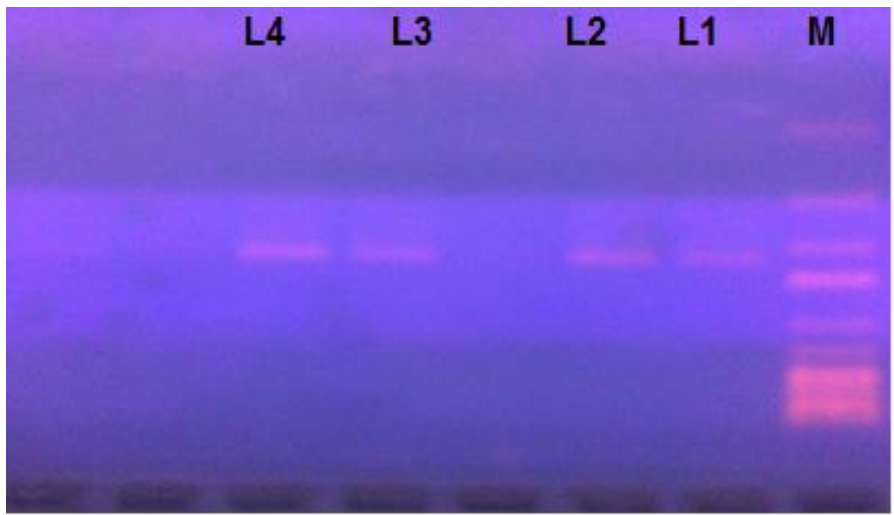

M: Molecular marker

L1,L2,L3,L4 positive species for IMP gene

All of the isolated MBLs Klebsiella pneumoniae strains were susceptible to tigecycline and $92.3 \%$ of isolates were susceptible to colistin. These findings are similar with other reports (43-45).

Laboratory screening methods for carbapenemase production include phenotypic methods like double disc test and combined disc assay beside molecular methods such as PCR amplification, and DNA sequencing (43). In the present study, both the combined disc test and double disc methods detected MBL production positive results within all resistant strains Klebsiella pneumoniae which were resistant to carbapenem antibiotics by disc diffusion test $(16,42)$. Franklin et al. (16) also reported that both methods are accurate screening tools. These results suggest that both tests can be used as a convenient routine method for detection of MBL producing $K$. pneumoniae isolates

Besides disc methods for screening of MBLs production, molecular detection of carbapenemase genes is an interesting rapid alternative, yet, its high cost and 
requirement of good experience in molecular laboratory techniques limit its uses. However, its use remains essential for epidemiological studies.

The most common identified gene responsible for MBLs-Klebsiella pneumoniae was VIM (69.2\%) followed by IMP and NDM (23.1\% for each) and mixed genotypes were identified in $23.1 \%$. Many of the carbapenem-resistant Enterobacteriaceae outbreaks identified have been related to the production of carbapenemases, the metallo-betalactamases genes VIM and IMP (44).

Similar results were obtained previously from Egypt 2012 on limited number of Klebsiella pneumoniae by Abdulall et al., 2014(14) and Abdelaziz et al. (2013)(45), demonstrating that IMP and VIM genes were common among MBLs-Klebsiella pneumoniae producing strains. However, our report is the first to report the presence of NDM in Egypt.

The present study conclude from this study that carbanamenase production is a common finding among the isolates of Klebsiella pneumoniae among neonates with sepsis. Both double discs and combined discs methods are accurate as screening tool for detection of resistance to carbapenam drugs. Genotypes responsible for MBLs determined VIM and IMP genes as the main prevalent genes beside NDM. Extensive studies should be carried out to determine the prevalence of MBL-Klebsiella pneumoniae in other geographic locations in Egypt to assess the magnitude of the problem. Antibiotics tigecycline and colistin are suitable for treatment under strict laboratory supervision and strict infection control practices and antibiotic policies should be strengthened to avoid the blowout of these microbial bums in our hospitals.

\section{References}

1.Vinod Kumar CS, Kalappanavar NK, Patil $\mathrm{U}$ andBasavarajappa KG.Change in spectrum of microbial aetiology in relation to gestational age and birth weight and emergence of ESBL in tertiary neonatal intensive care units Int J Biol Med Res 2011;2:727-34.

2.Waheed M, Laeeq A andMaqbool S.The etiology of neonatal sepsis andpatterns of antibiotic resistance. $\mathbf{J}$ Coll Physicians Surg Pak 2003; 13:449-52.

3.Fahmey SS. Early-onset sepsis in a neonatal intensive care unit in BeniSuef, Egypt: Bacterial isolates and antibiotic resistance pattern. Korean Journal of Pediatrics. 2013;56(8):332-337.

4.Idris , A A. Angie T,M. S. Reem M. H and Sohilla L. M.Ab , Neonatal Sepsis and Antibiotic Susceptibility in Nicus of Cairo University Hospitals. J of Arab Child 2014,.25 (4),. $87-97$

5.Roy S, Datta S, Viswanathan R, Singh AK andBasu S. Tigecycline susceptibilityin

Klebsiellapneumoniae and Escherichia coli causing neonatal septicaemia (2007-10) and role of an efflux pump in tigecycline nonsusceptibility.

AntimicrobChemother

2013;68:1036-42.

6.WHO. Antimicrobial Resistance Global Report on surveillance.

7.Ambler RP: The structure of betalactamases. Philos Trans R SocLond B BiolSci 1980, 289:321-331. 4. Bush K, Jacoby GA: Updated functional classification of $\beta$ lactamases. Antimicrob Agents Chemother 2010, 54:969-976.

8.Patel G andBonomo RA: "Stormy waters 
ahead": global emergence of carbapenemases. Front Microbiol 2013, 4:48.

9.Walsh TR: Emerging carbapenemases: a global perspective. Int $\mathbf{J}$ Antimicrob Agents 2010, 36(Suppl 3):S8-S14.4.

10.Lee J, Patel G, Huprikar S, Calfee DP and Jenkins SG.Decreased susceptibility to polymyxin B during treatment for carbapenem-resistant Klebsiellapneumoniae infection. J Clin Microbiol. 2009 May; 47(5): 1611-2.

11.Performance standards for antimicrobial susceptibility testing. 17 Suppl. Vol. 27. Wayne, PA: Clinical Laboratory Standards; 2007. Clinical and Laboratory Standards Institute.

12.Behera B, Mathur P, Das A, Kapil A and Sharma V.An evaluation of four different phenotypic techniques for detection of MetalloBetalactamase producing Pseudomonas aeruginosa.Indian J Med Microbiol. 2008;26:2313.

13.Kumarasamy K. K., et al. Emergence of a new antibiotic resistance mechanism in India, Pakistan, and the UK: a molecular, biological, and epidemiological study. Lancet Infect. Dis. 2010:10:597-602

14.Abdulall AK, El-Mahallawy HA, Abdo SA and Aly NK. Emergence of Klebsiella pneumoniae clinical isolates harboring Klebsiella pneumoniae carbapenemase and metallo- $\beta$-lactamase in two hospitals in Egypt.New Egyptian J Microb. 2014:39,(1):1-13

15.El-Din E M. R S, El-Sokkary M M. A,Bassiouny $M \quad R$, and Hassan $R$. Epidemiology of Neonatal Sepsis and Implicated Pathogens: A Study from Egypt. BioMed Research International.2015,11pages 16- Franklin C, Liolios L and Peleg
AY: Phenotypic detection of carbapenemase susceptible metallobeta-lactamase-producing gramnegative bacilli inthe clinical laboratory. J Clin Microbiol 2006, 44:3139-3144.

17.Poirel L, Walsh TR, Cuvillier V and Nordmann P.Multiplex PCRfor detection of acquired carbapenemase genes .DiagnMicrobiol Infect Dis.2011 ;70(1):119-23.

18.Ellington MJ, Kristler J, Livermore DM and Woodford N. Multiplex PCR for rapid detection of genes encoding acquired metallo-beta-lactamases.J Antimicrob Chemother. 2007 Feb;59(2):321-2.

19.Demir Y, Zer Y and Karaoglan I.Investigation of VIM, IMP, NDM1, KPC and OXA-48 enzymes in Enterobacteriaceae strains.Pak J Pharm Sci. 2015 May;28(3):112733.

20.Bizzarro, M.J., Raskind, C., Baltimore, R.S. and Gallagher, P.G. Seventyfive years of neonatal sepsis at Yale: 1928-2003. Pediatrics,2005 3(116): 595-602.

21.Stoll, B.J., Hansen, N., Fanaroff, A.A., Wright, L.L., Carlo, W.A., Ehrenkranz, R.A., Lemons, J.A., Donovan, E.F., Stark, A.R., Tyson, J.E., Oh, W., Bauer, C.R., Korones, S.B., Shankaran, S., Laptook, A.R., Stevenson, D.K., Papile, L.A. and Poole, W.K. Late-onset sepsis in very low birth weight neonates: the experience of the NICHD neonatal research network. Pediatrics, (2002): 110(2): 285-291

22.Boo NY, Ng SF and Lim VK. A casecontrol study of risk factors associated with rectal colonization of extended-spectrum beta-lactamase producing Klebsiella sp. in newborn infants.J.Hosp.Infect.2005;61:68-74. 
23.Crivaro V, Bagattini M, Salza MF, Raimondi F, Rossano F, Triassi $\mathrm{M}$ et al. Risk factors for extendedspectrum beta-lactamase-producing Serratia marcescens and Klebsiella pneumoniae acquisition in a neonatal intensive care unit. J Hosp Infect 2007; 67: 135-141.

24.Wu, J.H., Chen, C.Y., Tsao, P.N., Hsieh, W.S. and Chou, H.C. 2009. Neonatal sepsis: a 6-year analysis in a neonatal care unit in Taiwan. Pediatr. Neonatol., 50(3): 88-95.

25.Ghotaslou R, Ghorashi Z and Nahaei MR. Klebsiella pneumoniae in neonatal sepsis: a 3-year-study in the pediatric hospital of Tabriz, Iran.Jpn J Infect Dis. 2007;60(2-3):126-8.

26. Moore KL, Kainer MA, Badrawi N, Afifi S, Wasfy M, Bashir M, Jarvis WR, Graham TW, el-Kholy A, Gipson R, Jernigan DB, Mahoney F. Neonatal sepsis in Egypt associated with bacterial contamination of glucose-containing intravenous fluids. Pediatr Infect Dis J. 2005 Jul;24(7):590-4.

27.American Academy of pediatrics.Red Book 2000. 25th ed., 2000: 20-26, 241-2, 537-543.

28- Ahmed A. S., Chowdhury M. A., Hoque M., and Darmstadt G. L. Clinical and bacteriological profile of neonatal septicemia in a tertiary level pediatric hospital in Bangladesh. Indian Pediatrics, vol. 39, no. 11, pp. 1034-1039, 2002.

29.Mugalu J., Nakakeeto M. K., Kiguli S., and Kaddu-Mulindwa D. H., Aetiology, risk factors and immediate outcome of bacteriologically confirmed neonatal septicaemia in Mulago hospital, Uganda," African Health Sciences, vol. 6, no. 2, pp. 120-126, 2006.

30.Shitaye D. Neonatal sepsis: bacterial etiologic agents and their antibiotic susceptibility pattern in Tikur Anbessa University Hospital [M.S. thesis], Addis Ababa University, Addis Ababa, Ethiopia, 2008

31.M. M. Meremikwu, C. E. Nwachukwu, A. E. Asuquo, J. U. Okebe, and S. J. Utsalo, "Bacterial isolates from blood cultures of children with suspected septicaemia in Calabar, Nigeria," BMC Infectious Diseases, 2005. vol. 5,

32.Li Z., Xiao Z., Zhong Q., Zhang Y., and $\mathrm{Xu}$ F. 116 cases of neonatal earlyonset or late-onset sepsis: a single center retrospective analysis on pathogenic bacteria species distribution and antimicrobial susceptibility," Intern $\mathrm{J}$ of Clin and ExperMedi, (2013) vol. 6( 8): 693699.

33.Moore KL, Kainer MA, Badrawi N, Afifi S, Wasfy M, Bashir $M$ et al. Neonatal sepsis in Egypt associated with bacterial contamination of glucose-containing intravenous fluids. Pediatr Infect Dis J 2005; 24 : 590-594.

34.Jain A and Mondal R. Prevalence \& antimicrobial resistance pattern of extended spectrum beta-lactamase producing Klebsiella spp isolated from cases of neonatal septicaemia Indian J Med Res 2007; 125: 89-94.

35.Lee K, Yong D, Choi YS, Yum JH, Kim JM, Woodford $\mathrm{N}$ et al. Reduced imipenem susceptibility in Klebsiella pneumoniae clinical isolates with plasmid-mediated CMY-2and DHA1 beta-lactamases co-mediated by porin loss. Int J Antimicrob Agents 2007; 29: 201-206.

36.Agodi A, Barchitta M, Quattrocchi A, Maugeri A, Aldisio E, Marchese AE, Mattaliano AR and Tsakris A. Antibiotic trends of Klebsiella 
pneumoniae and Acinetobacter baumannii resistance indicators in an intensive care unit of Southern Italy, 2008-2013.Antimicrob Resist Infect Control. 2015 Nov 3;4:43.

37.European Centre for Disease Prevention and Control .Antimicrobial resistance surveillance in Europe 2012. Annual report of the European Antimicrobial Resistance Surveillance Network (EARSNet) Stockholm: ECDC; 2013.

38. Magiorakos AP, Srinivasan A, Carey RB, Carmeli Y, Falagas ME, Giske CG, et al. Multidrug-resistant, extensively drug-resistant and pan drug resistant bacteria: an international expert proposal for interim standard definitions for acquired resistance. Clin Microbiol Infect. 2012;18:268-81.

39. Magiorakos AP, Suetens C, Monnet DL, Gagliotti C, Heuer OE, EARS-Net Coordination Group and EARS-Net participants The rise of carbapenem resistance in Europe: just the tip of the iceberg? Ant Res Infect Control. 2013; 2:6. doi: 10.1186/2047-2994-2-6.

40.Bush K, Jacoby GA. Updated functional classification of betalactamases. Antimicrob Agents Chemother.2010;54:969-76.

41.European Centre for Disease Prevention and Control. Risk assessment on the spread of carbapenemase-producing Enterobacteriaceae (CPE) through patient transfer between healthcare facilities, with special emphasis on cross-border transfer. Stockholm: ECDC; 2011.

42.Bora A, Ahmed GU, Hazarika NK, Prasad KN, Shukla SK, Randhawa V andSarma JB: Incidence of bla NDM-1 gene in Escherichia coli isolates at a tertiary care referral hospital in Northeast India.Ind $\mathbf{J}$ of Med Microb,:2013, : 31( 3) : 250256

43.Ramana KV, Rao R, Sharada CV, Kareem M, Reddy LR, Ratna Mani M Modified Hodge test: a useful and the low-cost phenotypic method for detection of carbapenemase producers in Enterobacteriaceae members J Nat SciBiol Med., 2013, 4:346-348.

44.Perry JD, Naqvi SH, Mirza IA, Alizai SA, Hussain A, Ghirardi S, Orenga S, Wilkinson K, Woodford N, Zhang J, Livermore DM, Abbasi SA, Raza MW: Prevalence of the faecal carriage of Enterobacteriaceae with NDM-1carbapenemase at military hospitals in Pakistan, and the evaluation of two chromogenic media. J Antimicrob Chemother 2011, 66:2288-2294.

45.Abdelaziz M O.,C B A Aleo Fasciana T and Mammina C. NDM-1- and OXA-163 -producing Klebsiella pneumoniae isolates in Cairo, Egypt, 2012. J.Glob. Antimicrob. Resist, 2013, 1 (4):1-13

\section{How to cite this article:}

Maggie Mesbah, R., Maysaa El Sayed Zaki and Mona Abdel Latif Alsayed. 2016. Multiplex Polymerase Chain Reaction for Klebsiella pneumoniae Metallo- $\beta$-lactamase Causing Neonatal Sepsis in Mansoura Children University Hospital in Egypt. Int.J.Curr.Microbiol.App.Sci. 5(3): 194-205. doi: http://dx.doi.org/10.20546/ijcmas.2016.503.024 